УДК 141.201:37.013.73

DOI https://doi.org/10.32837/apfs.v0i32.1016

\author{
P. М. Богачев \\ ORCID ID: https://orcid.org/0000-0003-1926-608X \\ кандидат філософських наук, доцент, \\ завідувач кафедри філософіі \\ Національного технічного університету України \\ «Київський політехнічний інститут» \\ І.В.Богдановський \\ ORCID ID: https://orcid.org/0000-0001-5292-2195 \\ доктор філософських наук, професор, \\ професор кафедри філософії та політології \\ Університету Державної ріскальної служби України \\ О. Г. Льовкіна \\ ORCID ID: https://orcid.org/0000-0003-1825-8504 \\ доктор філософських наук, професор, \\ професор кафедри психологї̈ та соиіологї \\ Університету Державної ріскальної служби України
}

\title{
ПАРАДИГМА РОЗВИТКУ СОЦІОГУМАНІТАРНОГО ЗНАННЯ Й ОСВІТИ В ІНФОРМАЦІЙНОМУ СУСПІЛЬСТВІ
}

Постановка проблеми в загальному вигляді та ii зв'язок із важливими науковими чи практичними завданнями. Подолання нинішньої системної кризи розвитку людської цивілізації, симптомом якої є загострення глобальних проблем (економічних, екологічних, демографічних тощо), i, відповідно, перехід до нової парадигми сталого розвитку - «системи природа-суспільство-людина», неможливо здійснити без заміни застарілої освітньої парадигми. Щоб зберегти людство від самоліквідації, сучасна освіта повинна формувати людину не лише раціонально мислячу, а й творчу, і відповідальну. Така людина повинна прагнути не лише брати від природи, суспільства та інших людей, а й віддавати й збагачувати навколишній світ. Проте завдання розгляду тенденцій розвитку сучасного соціогуманітарного знання в інформаційному суспільстві, осмислення необхідності формування нової освітньої парадигми є складними для вирішення, адже, по-перше, саме гуманітарне знання є багатогранним і суперечливим феноменом; по-друге, наявні нині тенденції розвитку знань можна окреслити лише в найзагальнішому вигляді, спираючись на екстраполяцію, моделювання й експертну оцінку тих їх властивостей, які проявилися сьогодні досить ясно та в силу цього стали доступними для спостереження й усвідомлення; по-третє, більшість майбутніх властивостей соціогуманітарного знання не відомі нам у силу того, що матеріальний складник людського існування нині стрімко змінюється. Але необхідність такого дослідження є очевидною, адже традиційна система освіти продовжує готувати людей до життя в межах застарілої концепції кількісного економічного зростання, нестримної експлуата- ції природних ресурсів і безмежного й бездумного споживання. Відповідно, сучасна наука та освіта й досі слугують споживацькій цивілізації, яка прагне якомога більше взяти від природи.

Аналіз досліджень і публікацій із цієї теми, виділення не вирішених раніше частин загальної проблеми, котрим присвячується стаття. Інформаційно-постіндустріальна проблематика є однією з провідних тем сучасної філософії, соціології та політології. Серед відомих авторів, які розробляли цю тему, варто згадати Д. Белла, О. Білоруса, О. Вартанову, П. Дракера, М. Кастельс, М. Маклюена, Е. Масуду, М. Пората, М. Постера, Д. Рісмана, Т. Стоуньєра, Е. Тоффлера, Ф. Уебстера й інших. Основною тенденцією розвитку інформаційного суспільства є перехід до нової моделі комунікації - «людина-апарат», де штучна віртуальна реальність поступово замінює собою природну. На початку XXI ст. зростає значення не стільки самої інформації в різних сферах життя, скільки знань, що породило низку нових назв $\mathrm{i}$ визначень постіндустріального суспільства, серед яких найбільш поширилося «Knowledge Society» («суспільство знань»). Головним ресурсом цього суспільства знань стає освіта. Тенденції розвитку знання та проблематика інновацій в освіті досліджені в працях 3. Абасова, Л. Базиль, Л. Буркової, О. Дубасенюк, В. Загвязинського, І. Ільїнського, I. Коновальчука, С. Ніколаєнко, В. Паламарчука, Л. Подимової, О. Попової, В. Сластьоніна, О. Чумак, Н. Юсуфбекової, Т. Яровенко й інших. Проте тема формування нової освітньої парадигми на основі пріоритету саме соціогуманітарного знання досліджена ще недостатньо, що й зумовило необхідність розгляду нами зазначеної проблематики. 
Формулювання мети статті. У статті обгрунтовується необхідність формування й упровадження нової освітньої парадигми, орієнтованої на пріоритетний розвиток особистості, тобто такого типу освіти, провідним компонентом якої соціогуманітарне знання.

Виклад основного матеріалу дослідження. Суттєва риса постіндустріальної стадії розвитку цивілізації полягає в переході від пріоритету виробництва машин і речей до розвитку виробництва послуг, тобто освіти, охорони здоров'я, управління та наукових досліджень. Одну з найвідоміших концепцій інформаційного суспільства запропонував Е. Тоффлер. У книзі «Третя хвиля» він зазначив, що постіндустріальному суспільству притаманні такі основні риси, як деконцентрація виробництва й населення, різке зростання інформаційного обміну, превалювання самоврядних політичних систем, подальша індивідуалізація особистості при збереженні солідарних відносин між людьми та спільнотами. Він особливо виділяє індивідуальну трудову діяльність на дому й пише: «Ще за життя нашого покоління ... фабрики й установи наполовину спорожніють і перетворяться на складські або житлові приміщення. Коли ... ми отримаємо техніку, що дає змогу в кожному будинку обладнати недороге робоче місце, оснащене «розумною» друкарською машинкою, а може ще й копіювальною машиною або комп'ютерним пультом і телекомунікаційним пристроєм, то можливості організації роботи вдома різко зростуть» [1]. Нинішній стан справ у сфері виробництва показує, наскільки правим виявився Е. Тоффлер, адже за допомогою нових технологій маса людей отримала можливість повноцінно дистанційно спілкуватися, учитися і працювати.

На думку О. Вартанової, майже всі сучасні дослідники феномена інформаційного суспільства й цифровізації приходять до проблеми «суспільства знань»: «До теперішнього часу велика частина теоретиків пов'язує становлення інформаційного суспільства не стільки з технологічним розвитком, скільки з якістю інформації, поширюваної по комп'ютерних мережах... Концепція інформаційного суспільства перетворюється на концепцію суспільства знань (knowledge society, knowledgeable society, knowledge-based society)» [2, c. 48].

На наших очах відбувається цифровізація майже всіх соціально значущих послуг. Зокрема, адміністративні, юридичні, фінансові, освітні тощо послуги надаються в інтерактивному режимі. Кожна достатньо підготовлена для цього людина отримуе можливість через свої електронні пристрої отримувати необхідну для неї інформацію прямо зі свого будинку, не звертаючись особисто до магазинів і банків; бізнес структури обмінюються інформацією між собою електронним шляхом, знижуючи обсяг паперового документообігу і при цьому по- кращуючи якість послуг. Величезний потенціал мистецтва, літератури й науки стає доступним не тільки в бібліотеках і музеях. Освіта в цьому процесі не пасе задніх, оскільки найкращі навчальні заклади та викладачі стають доступними всім студентам онлайн незалежно від географічних умов.

На наше переконання, окрім подальшого переходу освіти в онлайн (у домінуванні цієї тенденції вже ніхто не сумнівається), будуть проявлятися й такі освітні тенденції, як гуманізація, відкритість тощо. Гуманізація полягає в утвердженні людини як найвищої соціальної цінності та стверджує створення нового зразка освіти, який передбачає пріоритет освіти, орієнтованої на особистість учня; формування духовності, культури особистості, планетарного мислення, цілісної картини світу. Відкритість системи освіти означає, що визначення цілей освіти не обмежується державним замовленням, а розширюється тими потребами в освіті, які привносять учні, їхні батьки, учителі; програми задають лише необхідний орієнтир-мінімум, загальне ядро знань, яке відкрите для доповнень, що залежать від культурних, регіональних, етичних та інших умов освіти.

Не все в розвитку сучасної інформаційної цивілізації е радісним і прекрасним. Поглиблення глобальних проблем (економічних, екологічних, демографічних тощо) свідчить, що сьогодні світ переживає перманентну кризу. Його губить принцип практичної користі, що, у свою чергу, є наслідком послідовно дотриманого раціоналізму. Освіта, обслуговуючи таку парадигму розвитку, лише прискорює рух цивілізації до катастрофи. Сьогоднішня домінантна консервативна парадигма освіти будується на принципах оптимізації, інтенсифікації, уніфікації навчального процесу, типізації та стандартизації навчальних планів і програм. Вона орієнтується передусім на потреби розвитку економіки, зумовлює «технологізацію» свідомості людини, практично залишаючи осторонь емоційно-чуттєву, моральну сторону структури особистості. Із цього випливає, на наше переконання, необхідність розробки й упровадження нової освітньої парадигми.

Зазначимо, що сьогодні не існує однозначного підходу до концептуалізації освітніх парадигм. В. Калін виділяє такі парадигми: по-перше, традиціоналістсько-консервативну парадигму, основним елементом якої є система «готових», «завершених» знань, умінь і навичок, яка транслюється студентам (при цьому сам студент $€$ переважно пасивним об'єктом у навчально-пізнавальній діяльності); по-друге, технократичну парадигму освіти, в якій організація навчання й виховання на відбувається основі репродуктивної діяльності осіб, які навчаються, спрямованої на ефективне досягнення чітко фіксованих еталонів засвоєння знань і досвіду; при цьому формується 
світогляд, за якого спостерігається перевага засобів над метою, цілей технологічної цивілізації над загальнолюдськими інтересами, техніки над цінностями; по-третє, біхевіористську (раціоналістичну) парадигму, яка розглядає навчання у виші як шлях засвоєння студентами знань з метою формування в них «правильної» поведінки, провідний принцип такої освіти - регулювання зовнішніх умов процесу й реакція на нього студентів, які засвоюють соціально прийнятний набір способів поведінки; по-четверте, гуманістичну парадигму, яка ставить у центр уваги розвиток студента, його інтелектуальні потреби й міжособистісні взаємини, ïï ядром є гуманістичний підхід до студента, допомога в його особистому зростанні [3, с. 44]. Зазначимо, що гуманістична освітня парадигма нині ще формується.

Одним із перших на початку XXI ст. почав писати про необхідність розробки й упровадження нової освітньої парадигми на основі гуманітаризації освіти I. Ільїнський. Він наголосив, що вищий сенс освіти в XXI ст. і їі місія - урятувати людство від нього самого. Це можна зробити, поставивши цінності гуманізму вище над усіма іншими сферами - економікою, політикою тощо. Звідси походить пріоритет соціально-гуманітарного знання й наук цього профілю перед природознавством. Створення нової парадигми освіти спричинить освітню революцію. Мова йде про освітню парадигму, побудовану на основі синтезу природознавства й суспільствознавства, але саме гуманітарне знання має стати провідною ланкою в їх діалектичному взаємозв' язку. Освіта має бути заснована на світорозумінні, що Ірунтується на концепції сталого розвитку [4, с. 35$]$.

Зазначимо, що наявні сьогодні в Україні освітньо-педагогічні практики в більшості своїй походять із радянської школи. Вони засновуються на діяльнісній моделі соціалізації й передбачають поетапне формування розумових здібностей завдяки використанню розвиваючих і проблемних методик навчання. Маючи низку безумовних переваг, ця освітня модель має той загальний недолік, що є застарілою, оскільки відображає потреби й реалії індустріальної епохи. Відповідно, в автентичному вигляді ця модель не може бути інтегрована 3 новою моделлю освіти, оскільки її подальше застосування призводить до гострого дефіциту людей, які мають широку гуманітарну ерудицію, тобто таких людей, які здатні глибоко проаналізувати широке коло загальнозначущих проблем суспільства й запропонувати шляхи їх вирішення.

Сучасна криза суспільства - це значною мірою аксіологічна криза. Відповідно, вища освіта повинна вивести суспільство з глибокої кризи цінностей, забезпечити вихід за рамки суто економічних міркувань. Революційність змін в освіті передбачає необхідність розробки нової освітньої парадигми, поява якої сама по собі становитиме теоретичну основу практичної освітньої революції [5, с. 136]. Ця нова освітня парадигма повинна містити в собі кілька основних ідей і підходів: по-перше, це новий погляд на місію освіти у XXI ст.; по-друге, варто виробити новий погляд на предмет і кінцеві цілі освіти; по-трете, варто усвідомити провідну роль соціально-гуманітарного знання.

Підхід до розв'язання цивілізаційної кризи можна сформулювати таким чином: ми зможемо вижити, якщо будемо увесь час розвиватися. Виживання через розвиток - ось формула нашого майбутнього успіху. Відповідно, до системи освіти, крім механізму сприйняття інформації, вироблення умінь і навичок, має бути добавлене завдання формування здатності до розуміння перспектив виживання людства на основі концепції сталого розвитку. Ця концепція відрізняється від усіх попередніх ідеологій, які претендували на універсалізм і глобалізм, тим, що має переважно соціальний, а не політичний характер, орієнтує на розвиток та оптимальне використання людського потенціалу в гармонії з природою.

Освіта як суспільно-організований, нормований і цілісний процес засвоєння культури є насамперед процесом виховально-освітнім. Саме тому освіта покликана реалізувати мету виховання, визначену потребами сучасного українського суспільства. Одним із основних засобів реалізації мети виховання є зміст освіти. У традиційній педагогіці він зорієнтований головним чином на знання як відображення духовного багатства людства, тобто освіта є орієнтованою на засвоєння певного фонду знань: символів і формул, імен, дат і фактів, понять і термінів, а також зв'язків і залежностей між ними, відображених у правилах. Знання, безумовно, є важливими соціальними цінностями, які сприяють соціалізації особистості, а репродукування знання відображує структуру сучасної науки, урізноманітнює знання й із точки зору сцієнтизованого способу оцінювання покращує якість освіти. У вітчизняній теорії і практиці навчання й виховання знання стали самі по собі абсолютними цінностями, заступили собою власне людину. Така освіта 3 притаманними їй директивно-наказовими рисами не відповідає запитам сучасності. Крім того, тут варто згадати вислів Геракліта, що «знання розуму не навчають» .

Внутрішній сенс революції освіти полягає в переході на більш високий рівень розуміння знань. Необхідно замінити традиційну інформаційно-транслюючу педагогічну парадигму на особистісно-творчу педагогіку розуміння. Сучасна освіта не вимагає від учнів і студентів запам'ятовування якомога більшої кількості інформації. Досвід педагогів-новаторів ясно показує, що лише освітній процес зорієнтований на розуміння, а не запам'ятовування матеріалу, суттєво підвищує 
ефективність навчання. У цьому контексті варто приділити увагу розвитку творчих здібностей, адже саме творчість долає фрагментарність уявлень про світ, сприяє кращому впорядковуванню життя, надаючи йому інші, більш високі смисли, тобто дає змогу побачити світ цілісним і гармонійним, не втрачаючи в ньому себе самого. 3 іншого боку, існує тенденція «технологізації» гуманітарного знання. На наше переконання, до сучасного гуманітарного знання самим суспільством ставиться вимога розробки гуманітарних технологій, які здатні суттєво посилити людський творчий потенціал. Гуманітарні технології знаходять попит і використовуються в найрізноманітніших сферах: економічній (бізнес-тренінги), політичній (мас-медійні технології, PR-технологіï), психологічній тощо. На наше переконання, щоб не відставати від життя, в школі та виші потрібно створювати й упроваджувати спеціальні методики і тренінги, що розвивають творчі здібності, без яких людина зводиться до функції, здатної лише грати певну роль, а не творити, тобто перетворюється на культурно обмеженого технократа.

Протягом останніх десятиліть усе більше стверджується особистісно-орієнтований підхід до виявлення суті змісту освіти, який передбачає, що абсолютною цінністю змісту освіти є не відчужені від особистості знання, а сама людина. Особистісно-орієнтований зміст освіти забезпечує розвиток цілісної людини, яка прагне до максимальної реалізації своїх можливостей (самоактуалізації), відкрита до сприйняття нового досвіду. Особистісно-орієнтована освіта - це антропоцетрична освіта, котра базується на врахуванні самобутності, самоцінності учня та суб'єктності процесу навчання, забезпечує розвиток бажаних і гальмує неприязні тенденції, убачатиме в особистій творчій самореалізації найвищий сенс життя. У такому розумінні гуманізація освіти, сприятиме перетворенню позиції педагога й позиції учня в особистісно-рівноправні. Таке перетворення пов'язане зі зміною ролей і функцій учасників педагогічного процесу. Педагог не виховує і не вчить, а активізує і стимулює, тобто формує мотиви учня до саморозвитку і створює для цього умови.

У цьому контексті варто погодитися з О. Чумак, яка зазначає, що в новій освітній парадигмі, викладачі мають створювати «активне навчальне середовище для студентів, але самі не обов'язково мають бути залученими до окремих форм навчальної активності. Головне - сформувати потяг і творче ставлення до навчання, створити для цього відповідні умови. Саме тому західні університети переходять на цілодобовий доступ до бібліотек, Інтернету та іншої інфраструктури навчання для забезпечення самостійної роботи студентів... Нова парадигма вищої освіти - парадигма гуманістична за своєю суттю, передбачає, що її головною ланкою буде окрема людина. Максимальне розкриття її індивідуальних здібностей, неповторних, унікальних особливостей психіки та інтелекту стають головною метою всього освітнього процесу» [6].

Має відбутися перенесення акценту з навчальної діяльності на навчально-пізнавальну й перехід від переважно інформативних до активних методів і форм навчання з використанням елементів проблемності, наукового пошуку, резервів самостійної роботи тих, хто навчається. Іншими словами, варто забезпечити перехід від відтворення до розуміння, осмислення навчання. Усе це сприятиме створенню умов для самоствердження, самореалізації й самовизначення особистості.

На наш погляд, зміни потрібно впровадити й у самий зміст гуманітарного складника вищої освіти. Компонентами цього нового змісту й розуміння мають бути, по-перше, екологізація мислення як умова виживання людства та його переходу на шлях сталого розвитку й збереження культурної різноманітності; по-друге, зміна розуміння філоcoфiї якості, у тому числі якості життя, яка передбачає, зокрема, створення мотивації на активну діяльність щодо вдосконалення якості (інтелектуальної, духовної, моральної і фізичної) своєї праці і своєї особистості.

У XXI ст. знання зростають та оновлюються темпами, що багаторазово перевищують попередні епохи. У цій ситуації ні вчителі, ні викладачі вишів не зможуть дати вичерпних знань, необхідних людям для всього їхнього життя. Необхідні їй знання людина повинна навчитися отримувати індивідуально, а для цього вона має бути мотивованою й отримати звичку та навичку самостійного пошуку нових знань. Крім того, для людини найважливішою якістю має стати бажання i здатність бачити не тільки вчорашній і сьогоднішній, а й завтрашній день. Але забезпечення такої можливості передбачає, що сама система освіти буде спрямована на випереджувальний розвиток особистості. Відповідно, нова освітня парадигма має передбачити формування в учнівської молоді творчого ставлення до фундаментальних та актуальних знань, що дасть змогу майбутнім спеціалістам не тільки встигати за лавиноподібним зростанням знань та інформації, а й випереджати цю «лавину», формуючи як нове виробництво, техніку й технології, так і нові способи освоєння знань, адже саме освіта за самою своєю суттю покликана працювати на майбутне, закладаючи основу майбутніх змін у суспільстві. Випереджаючий розвиток освіти означає, що вона не лише успішно адаптується до зовнішнього середовища, відповідає потребам особистості, суспільства, виробництва, а й сама активно впливає на стан особистості й суспільства, зумовлює та формує їхні потреби, використовуючи наукове передбачення, прогнозування найближчих і віддалених перспектив 
цивілізаційного розвитку, а не тільки запитів виробництва. Краще майбутнє навряд чи виникне 3 хаосу, щоб воно настало, його треба формувати, програмувати, свідомо та прискорено змінюючи картину світу і світорозуміння нових поколінь.

Ще одним складником нової парадигми освіти є ідея їі безперервності. Варто обирати реальні шляхи переходу від старої конструкції «освіта на все життя» до нової конструкції - «освіта через усе життя» . Безперервність освіти означає, що людина вчиться постійно, без тривалих перерв, переходить від одного виду освітньої діяльності до іншого, з більш низького рівня на більш високий. Безперервність освіти повинна забезпечити максимальну можливість успішного руху особистості в інтелектуальному просторі соціуму. Уже сьогодні освіта не обмежена жорсткими термінами навчання й набуває рис постійного складника в життєдіяльності багатьох людей, які не уявляють процес свого вдосконалення без постійної освіти та самоосвіти.

Висновки 3 дослідження й перспективи подальших пошуків у цьому напрямі. Ми вважаємо, що нова освітня парадигма для суспільства XXI ст. буде характеризуватися гуманізацією освітнього процесу, у тому числі гуманітаризацією його змісту. Ця нова освітня парадигма повинна орієнтувати на формування людяної особистості, здатної перебувати в гармонії з іншими людьми і природою. Проте не варто розуміти це таким чином, що точні науки і природознавство втратять свою цінність і що соціогуманітарне знання витіснить або замінить їх. Ні. Ми наголошуємо на тому, що знання про людину, культуру, суспільство, буття, свідомість, політику, історію почне займати (і з часом займе!) належне йому центральне місце в системі освіти й виконуватиме провідну роль як у свідомості окремої особистості, так і в суспільстві, сприяючи їхньому гармонійному розвитку. Для успіху впровадження нової освітньої парадигми має відбутися синтез розуму і почуття; знань і виховання, адже навчання без виховання $€$ неповноцінним, саме по собі воно може принести більше шкоди, ніж користі, оскільки отримані знання можуть бути використані не на благо, а на зло. Відповідно, якщо ми говоримо про людину, то варто мати на увазі не тільки їі розумові здібності, a i ïï емоційну, чуттєву, духовну сторони, які створюються не стільки навчанням, скільки (і передусім) вихованням. Крім того, сенсом сучасної освіти має стати навчання творчості через активізацію совісті, розуму й емоцій, які в єдності здатні забезпечити успішність процесу пристосування до умов життя, що перманентно змінюються й часто наперед невідомі, а це, у свою чергу, сприятиме досягненню кращих результатів.

Щоб протистояти невизначеності, що зростає, i непередбачуваності, які неймовірно ускладнюють життя й породжують масу несподіваних, нетриві- альних завдань, суспільство мусить через систему освіти свідомо формувати гармонійну людину нового типу, яка має рівномірно розвинені творчі здібності, інтелект, емоційно-вольову й духовно-моральну сторони своєї особистості. Тому й виникає новий ідеал-парадигма освіти, у центрі якого - людина в їі повному вимірі (як єдність тіла, розуму, емоцій і душі), здатна жити в гармонії 3 природним і культурним середовищем.

\section{Jimepamypa}

1. Тоффлер Э. Третья волна. URL: http://www. gumer.info/bibliotek_Buks/Culture/Toffler/_08.php (дата звернення: 06.11.2021).

2. Вартанова Е.Л. Медиаэкономика зарубежных стран. Москва : Аспект Пресс, 2003. 335 с.

3. Калин В.И. Парадигмы образования в современной мировой педагогической практике. Соціальногуманітарні вектори педагогіки вищої школи : збірник матеріалів II Міжнародної наукової конференції, м. Харків, ХДАДМ, 15-16 квітня 2010. Харків : ХДАДМ, 2010. С. 44-46.

4. Ильинский И.М. Образовательная революция. Москва : Московская гуманитарно-социальная академия, 2002. $594 \mathrm{c.}$

5. Богдановський І.В., Воробйова Л.С. Соціогуманітарне знання як основа формування нової освітньої парадигми для глобального «суспільства знань» : монографія. Ірпінь : Університет Державної фіскальної служби України, 2017. 200 с.

6. Чумак О.В. Парадигма освіти XXI століття: інноваційні аспекти. URL: http://virtkafedra.ucoz.ua/ el_gurnal/pages/vyp7/konf1/Chumak.pdf (дата звернення: 06.11.2021).

\section{Анотація}

Богачев Р. М., Богдановський I. В., Льовкіна О. Г. Парадигма розвитку соціогуманітарного знання й освіти в інформаційному суспільстві. - Стаття.

У статті розглядаються основні тенденції розвитку феномена освіти в глобалізованому інформаційному суспільстві. Наголошується на необхідності створення нової освітньої парадигми, яка буде характеризуватися гуманізацією всіх сторін освітнього процесу. До системи освіти, крім механізму сприйняття інформації, вироблення вмінь і навичок, має бути добавлено завдання формування здатності до розуміння перспектив виживання людства, виходячи зі стратегічних пріоритетів сталого розвитку суспільства. Зазначається, що необхідні їй знання людина повинна отримувати індивідуально, а для цього вона має бути мотивованою й отримати звичку та навичку самостійного пошуку нових знань. Для людини важливою якістю має стати бажання і здатність бачити не тільки вчорашній і сьогоднішній, а й завтрашній день. Забезпечення такої можливості передбачає, що сама система освіти буде спрямована на випереджувальний розвиток особистості. Знання про людину, культуру, суспільство, політику, історію 3 часом займе належне йому центральне місце в системі освіти й виконуватиме провідну роль як у свідомості окремої особистості, так і в суспільстві, сприяючи 
їхньому гармонійному розвитку. Акцент буде перенесено із суто навчальної діяльності на навчально-пізнавальну, що забезпечить перехід від переважно інформативних до активних методів і форм навчання 3 використанням елементів проблемності, наукового пошуку, активізації самостійної роботи. Усе це сприятиме створенню умов для самоствердження, самореалізації й самовизначення особистості. Особистісно орієнтований зміст освіти забезпечує розвиток цілісної людини, яка прагне до максимальної реалізації своїх можливостей і є відкритою до сприйняття нового досвіду. Важливим складником нової парадигми освіти є ідея їі безперервності. Безперервність освіти означає, що людина вчиться постійно, без тривалих перерв, переходить від одного виду освітньої діяльності до іншого, з більш низького рівня на більш високий. Наголошується, що впровадження нової освітньої парадигми дасть змогу свідомо формувати гармонійну людину нового типу, яка матиме рівномірно розвинені творчі здібності, інтелект, емоційно-вольову й духовно-моральну сторони своєї особистості. У центрі нової парадигми освіти буде перебувати людина в її повному виміpi (як єдність тіла, розуму, емоцій і душі), здатна жити в гармонії з природним і культурним середовищем.

Ключові слова: інформаційне суспільство, освіта, освітня парадигма, особистість, творчі здібності, розвиток.

\section{Summary}

Bogachev R. M., Bodanovskiy I. V., Leovkina E. G. Paradigm of development of socio-humanitarian knowledge and education in the information society. Article.

The main tendencies of development of the phenomenon of education in the globalized information society are considered in the article. It emphasizes the need to create a new educational paradigm, which will be characterized by the humanization of all aspects of the educational process. In addition to the mechanism of perception of information, development of skills and abilities, the task of forming the ability to understand the prospects of human survival, based on the strategic priorities of sustainable development of society, should be added to the education system. It is noted that a person must receive the necessary knowledge individually, and for this he must be motivated and get the habit and skill of independent search for new knowledge. Knowledge about people, culture, support, politics, history with an hour loan to the right central place in the system of education and visibility, I will play a role in the quality of the special features of harmony, as well as in the promotion. For the success in the implementation of the new educational paradigms, we see the synthesis of the rose and feel. An important quality for a person should be the desire and ability to see not only yesterday and today, but also tomorrow. Providing such an opportunity implies that the education system itself will be aimed at the advanced development of the individual. Personally oriented content of education provides the development of a holistic person who seeks to maximize their potential and is open to new experiences. An important component of the new paradigm of education is the idea of its continuity. Continuity of education means that a person learns constantly, without long breaks, moves from one type of educational activity to another, from a lower level to a higher one. It is emphasized that the introduction of a new educational paradigm will consciously form a harmonious person of a new type, who will have evenly developed creative abilities, intelligence, emotional, volitional and spiritual and moral aspects of his personality. At the center of the new paradigm of education will be a person in its full dimension (as the unity of body, mind, emotions and soul), able to live in harmony with the natural and cultural environment.

Key words: information society, education, educational paradigm, personality, creative abilities, development. 